\title{
THE EFFICACY OF THE WRF-ARW MODEL IN THE GENESIS AND INTENSITY FORECAST OF TROPICAL CYCLONE FANI OVER THE BAY OF BENGAL
}

\author{
Md. Shakil Hossain ${ }^{1 *}$, Md. Abdus Samad², S. M. Arif Hossen' ${ }^{1}$ S. M. Quamrul Hassan ${ }^{3}$ \\ and M A K Malliak ${ }^{3}$ \\ ${ }^{1}$ Department of Mathematics, Khulna University of Engineering \& Technology, Khulna 9203, Bangladesh \\ ${ }^{2}$ Department of Applied Mathematics, University of Dhaka, Dhaka 1000, Bangladesh \\ ${ }^{3}$ Bangladesh Meteorological Department, Dhaka 1207, Bangladesh
}

Received: 01 October 2021

Accepted: 28 December 2021

\begin{abstract}
An attempt has been carried out to assess the efficacy of the Weather Research and Forecasting (WRF) model in predicting the genesis and intensification events of Very Severe Cyclonic Storm (VSCS) Fani (26 April - 04 May 2019) over the Bay of Bengal (BoB). WRF model has been conducted on a single domain of $10 \mathrm{~km}$ horizontal resolution using the Global Data Assimilation System (GDAS) FNL (final) data $\left(0.25^{\circ} \times 0.25^{\circ}\right)$. According to the model simulated outcome analysis, the model is capable of predicting the Minimum Sea Level Pressure (MSLP) and Maximum Sustainable Wind Speed (MSWS) pattern reasonably well, despite some deviations. The model has forecasted the Lowest Central Pressure (LCP) of $919 \mathrm{hPa}$ and the MSWS of $70 \mathrm{~m} \mathrm{~s}^{-1}$ based on 0000 UTC of 26 April. Except for the model run based on 0000 UTC of 26 April, the simulated values of LCP are relatively higher than the observations. According to the statistical analysis, MSLP and MSWS at $850 \mathrm{hPa}$ level demonstrate a significantly greater influence on Tropical Cyclone (TC) formation and intensification process than any other parameters. The model can predict the intensity features well enough, despite some uncertainty regarding the proper lead time of the model run. Reduced lead time model run, particularly 24 to $48 \mathrm{hr}$, can be chosen to forecast the genesis and intensification events of TC with minimum uncertainty.
\end{abstract}

Keywords: Cyclogenesis; Intensity; MSLP; MSWS; SST; TC.

\section{INTRODUCTION}

TCs are one of the most destructive environmental issues around the world. The intensity of a TC is characterized by the MSWS and the MSLP around the system's center. The intense TC causes severe damage to lives and properties, especially throughout the coastal regions. Pre-monsoon (March-May) and post-monsoon (OctoberDecember) seasons are the favourable periods for the TC development over the BoB. During these periods, the monsoon channel prevails over the Indian Ocean and encourages low-pressure systems to develop into a strong Cyclonic Storm (CS) (Lee et al., 1989). Every year, the BoB is involved in around $7 \%$ of all TCs worldwide (Gray, 1968).

The severity of the cyclone has a major impact on the number of deaths and property damage. Every year, TCs, especially intense cyclones that cross over the BoB, cause huge damage to the low-lying coastal regions. As a result, the community of these states is extremely concerned about their growing challenges. Accurate cyclone forecasting may significantly decrease the loss of life and property in this region.

Over the last few decades, numerous researchers have carried out their efforts to develop proper cyclone forecasting approaches using several Numerical Weather Prediction (NWP) models. Sousounis et al. (2004) studied several precipitation events using the WRF, Rapid Update Cycle (RUC), Early ETA Forecast Model (ETA), and Fifth-Generation Mesoscale Model(MM5) models. They revealed that the WRF model can generate relatively better physically realistic fine-scale structures than any other model. The Kain-Fritsch (KF) convection, Purdue Lin (LIN) explicit microphysics schemes, Yonsei University (YSU) Planetary Boundary Layer (PBL), and NOAH land surface schemes are the suitable combination for precise intensity prediction (Srinivas et al., 2013). Hossain et al. (2021) studied the track and landfall of VSCS Fani over the BoB using WRF-ARW model. They concluded that the model is suitable enough to predict the CS over the BoB. Alam (2020) studied the sensitivity study of PBL parameterization schemes for the simulation of TC 'Fani' over the BoB using high resolution WRFARW model. He revealed that the intensity forecast of TC is significantly influenced by several PBL schemes.

Low-level vorticity, moist static instability and mid-tropospheric Relative Humidity (RH), Sea Surface Temperature (SST) above $26^{\circ} \mathrm{C}$ (up to a depth of $60 \mathrm{~m}$ ), the Coriolis parameter, and the inverse of the tropospheric vertical wind are the climatological parameters essential for cyclogenesis (Gray, 1968). The genesis and intensification events of TC are hampered significantly by relatively higher Vertical Wind Shear (VWS) values between 200 and $850 \mathrm{hPa}$ levels (Frank and Ritchie, 2001). Analyzing the correlation between SST and maximum 
potential intensity of TCs from 1981 to 2000, Kotal et al., (2009) observed that the maximum intensity of TC rises with increasing temperature. Cyclone activity is expected to increase as a result of global warming and sea-level rise. The forecast of warmer weather may potentially support more severe storms (Bender et al., 2010; Emanuel, 2005; Webster et al., 2005; Trenberth, 2005). Climate change is influencing significantly TC patterns and their severity in terms of wind speed is rising (Saha and Khan, 2014; Emanuel, 1991; Holland, 1997; Knutson and Tuleya, 2004). The frequency of severe storms (significantly greater than 115 knots) increased nearly doubled between 1990 to 2004, which is strongly connected to SST (Hoyos et al., 2006).

Since multiple TCs wreak havoc on coastal areas each year, it certainly feels to be a critical threat for the Indian subcontinent. It is important to forecast the behavior of TCs properly to alleviate the huge lossof life and property. If the genesis and development of cyclones can be reasonably predicted, it will be a significant step forward in management techniques. The effectiveness of the WRF-ARW model in predicting the cyclogenesis and intensification characteristics of the VSCS Fani is assessed in the current study. It is expected that this study will have a significant positive impact on future TC genesis and intensity predictions over the BoB.

\section{EVENT DESCRIPTION}

VSCS Fani was the most severe TC to strike the Odisha coast since Phailin in 2013, which had a MSWS of 215 $\mathrm{kmph}$. It developed in the early morning of 25 April near the equator $\left(2.7^{\circ} \mathrm{N}\right.$ and $\left.88.7^{\circ} \mathrm{E}\right)$ from a Low-Pressure Area (LPA) that formed across the east Equatorial Indian Ocean (EIO) and neighboring southeast BoB(IMD, 2019). The generated low-pressure system progressed into a Depression (D) on the morning of 26April due to the favorable weather conditions. On 27April, it intensified into a Deep Depression (DD) over the same zone early in the morning (0030 UTC) and then into a CS "Fani" around 0630 UTC across southeast BoB and adjacent east EIO.Moving north-northwestwards, it strengthened into a Severe Cyclonic Storm (SCS) about 1230 UTC of 29 April over central sections of south BoB. Moving northwards, it deepened into a VSCS in the morning of 30 April over southwest BoB.It quickly intensified throughout the west-central BoB from the afternoon of 29 April to the evening of 30April. From 0900 UTC to 2100 UTC on 02 May, the lowest Estimated Central Pressure (ECP) and the MSWS of the VSCS were $932 \mathrm{hPa}$ and $115 \mathrm{knots}$, respectively (IMD, 2019). The VSCS passed the Odisha coast near Puri with a MSWS of 100 knots between 0300 UTC to 0500 UTC on 3 May 2019. Even after making landfall, the system remained a CS for over $21 \mathrm{hr}$, until 0000 UTC of 4 May. At 0300 UTC of 4 May, proceeding north-northeastwards, it degraded into a DD across Bangladesh and neighboring Gangetic West Bengal. The system had a life span of $219 \mathrm{hr}$ between D to D (0330 UTC of 26 April to 0630 UTC of 4 May). The cyclone's track length was observed as $3030 \mathrm{~km}$ which was one of the longest over the BoB.

\section{DATA AND METHODOLOGY}

The WRF model (Skamarock et al., 2008) version 4.0.3 has been applied on a single domain of $10 \mathrm{~km}$ horizontal resolution for 180,156,132, 108, 84, 60, and $36 \mathrm{hr}$ based on initial conditions of 0000 UTC of 26April, 27 April, 28 April, 29 April, 30 April, 1 May, and 2 May 2019 to simulate the formation and intensification of the events of VSCS Fani. The position $\left(13^{\circ} \mathrm{N}, 87^{\circ} \mathrm{E}\right)$ was chosen as the domain's center point for all simulations. The number of grid points selected over the simulated region in the east-west and north-south directions is $(300 \times 300)$, whereas the vertical structure consisted of 38 unequally spaced sigma (dimensionless pressure) levels. The Kain-Fritsch (new Eta) cumulus parameterization scheme (Kain, 2004) and Kessler microphysics scheme (Kessler, 1969), Yonsei University (YSU) scheme for the PBL (Hong et al., 2006), Revised MM5 surface layer physics scheme (Jimenez et al., 2012), Unified Noah LS scheme for the land-surface model (Tewari et al., 2004), Dudhia shortwave radiation scheme (Dudhia, 1989), and the RRTM scheme for the longwave radiation (Mlawer et al., 1997) are the physics parameterization schemes that have been executed in the present study. The Mercator map projection has been applied during this study.

In the continued research, the National Center for Environmental Prediction (NCEP) FNL (Final) operational global analysis and forecast data $\left(0.25^{\circ} \times 0.25^{\circ}\right)$ has been used. The observed datasets of the India Meteorological Department (IMD)(IMD, 2019)and Bangladesh Meteorological Department (BMD) have been used to validate the model's predicted outputs.

\section{RESULTS AND DISCUSSION}

\subsection{Distribution of Mean Sea Level Pressure and Wind}

The distribution of model forecasted MSLP for the VSCS Fani (at the time of model predicted maximum intensity) has been depicted in Figure 1(a-g) respectively at 0000 UTC of 3 May, 2100 UTC of 30 April, 1200 UTC of 3 May, 1300 UTC of 2 May, 1300 UTC of 1 May, 0000 UTC of 3 May, and 1000 UTC of 2 May based on 0000 UTC of 26, 27, 28, 29 and 30 April, 1 and 2 May 2019. According to the model-predicted MSLP analysis, a wellstructured LPA system is simulated in the early morning of 26 April. According to the observations, the LPA was formed across the east EIO and neighboring southeast BoB in the early morning of 25 April. 

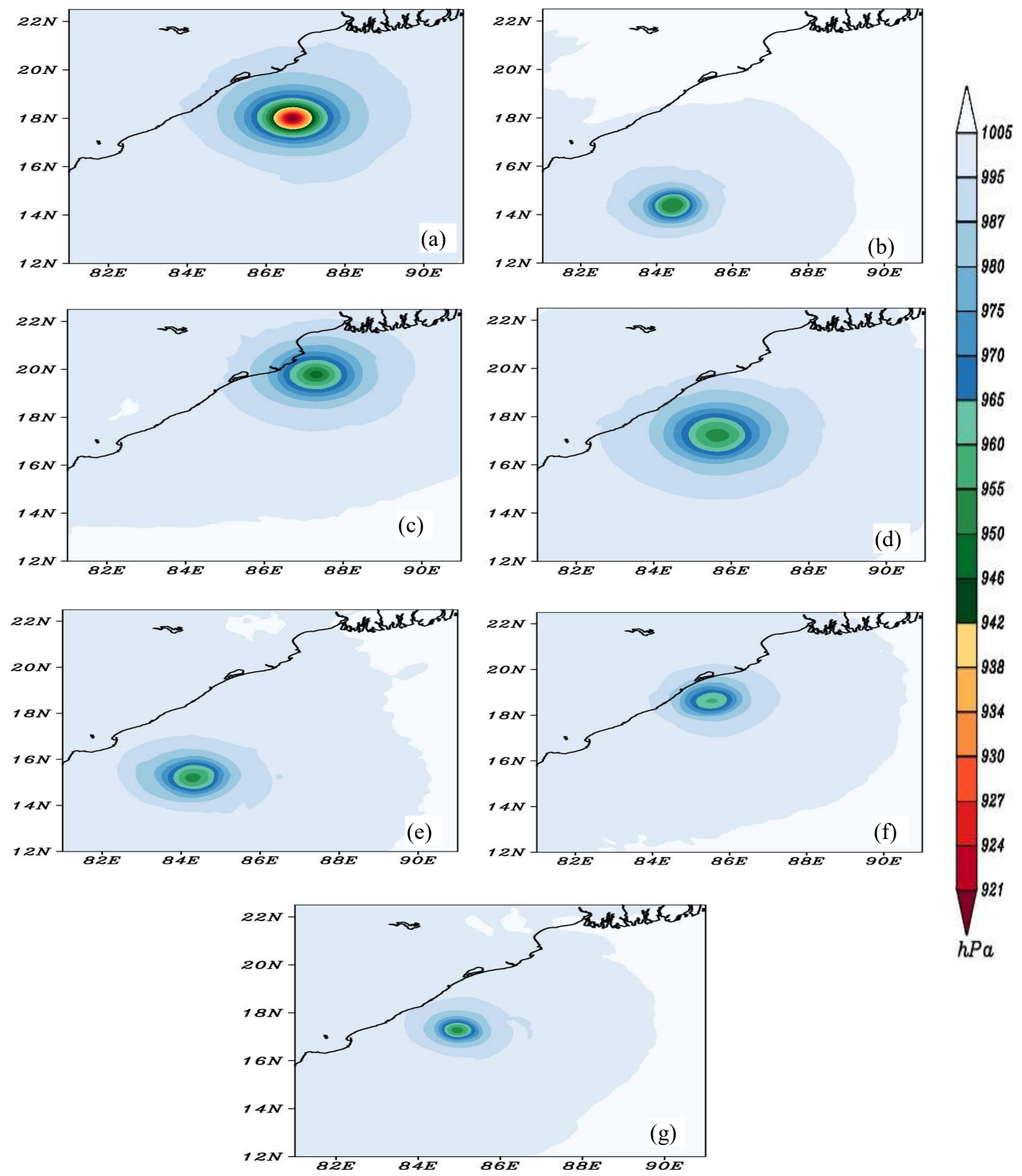

Figure 1: The distribution of model simulated MSLP (hPa) valid for (a) 0000 UTC of 3 May, (b) 2100 UTC of 30 April, (c) 1200 UTC of 3 May, (d) 1300 UTC of 2 May and (e) 1300 UTC of 1 May based on 0000 UTC of 26, 27, 28, 29 and 30 April, respectively and (f) 0000 UTC of 3 May and (g) 1000 UTC of 2 May based on 0000 UTC of 1 and 2 May 2019, respectively.

The model has simulated a downward trend in MSLP over time until it reached its maximum intensity. The system's core is well defined by several isobars. The number of isobars rises till the system attaints its peak intensity. Isobars exhibit strong pressure gradients over time. The model simulated LCP is found 919, 950, 950, 955, 953, 960, and $955 \mathrm{hPa}$ respectively based on 0000 UTC of 26, 27, 28, 29 and 30 April, 1 and 2 May 2019. The recorded ECP was $932 \mathrm{hPa}$. In each simulation, the system's minimal MSLP is obtained over the sea. It is worth mentioning that the simulated time and the minimal MSLP values varied for different initial conditionsbased model runs. 

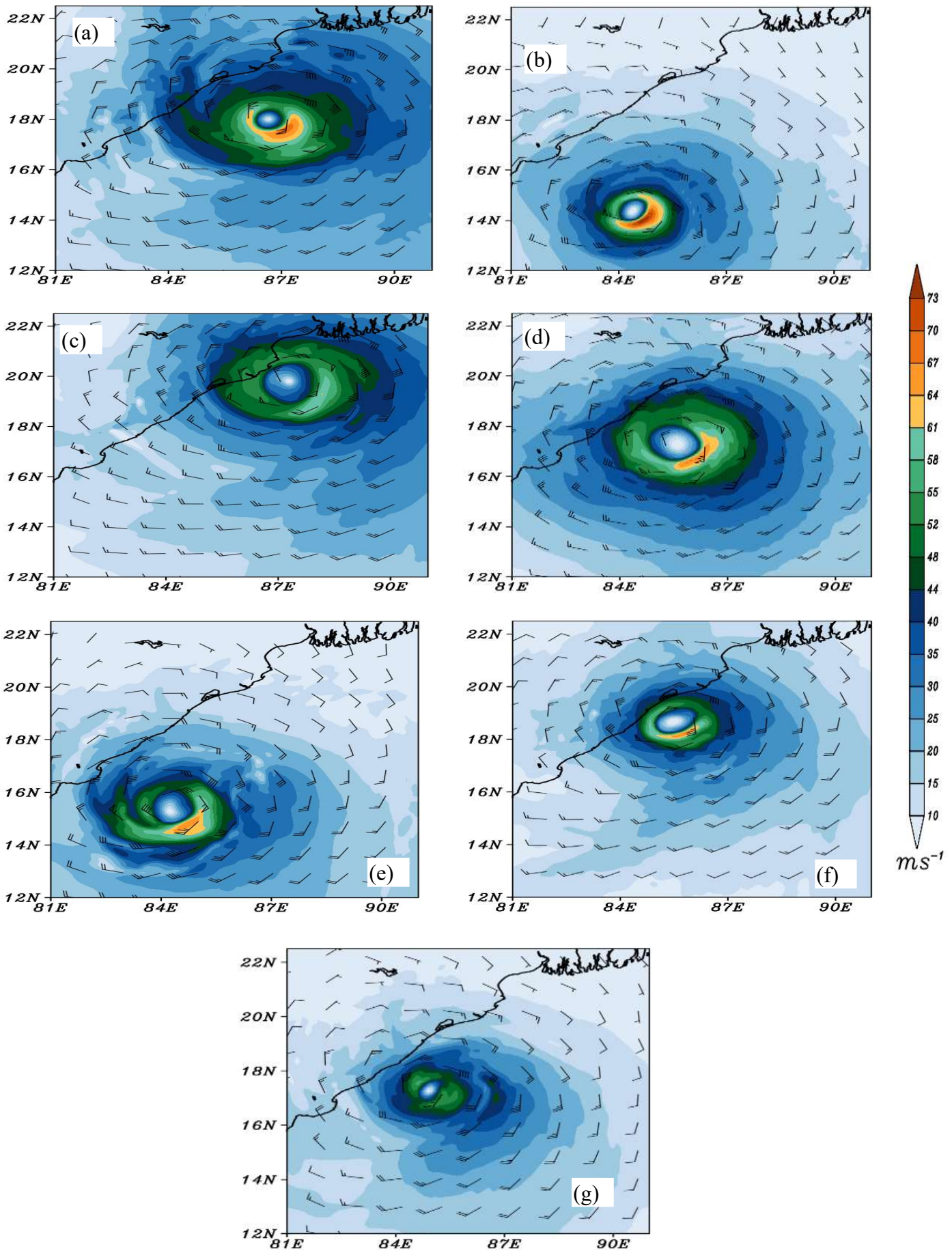

Figure 2: The distribution of model simulated wind speed $(\mathrm{m} / \mathrm{s})$ at $850 \mathrm{hPa}$ level valid for (a) 0000 UTC of 3 May, (b) 2100 UTC of 30 April, (c) 1200 UTC of 3 May, (d) 1300 UTC of 2 May and (e) 1300 UTC of 1May based on 0000 UTC of 26, 27, 28, 29 and 30 April, respectively and (f) 0000 UTC of 3 May and (g) 1000 UTC of 2 May based on 0000 UTC of 1 and 2 May 2019, respectively.

The simulated Minimum Central Pressure (MCP) has been compared with the ECP of IMD to evaluate the model's simulated outcomes (Figure 3(a-g)). It is found that the predicted MCP exhibits an identical pattern with the observed ECP. The simulated MCP values are comparatively higher than the observations. It is also determined that a relatively reduced lead-time model run can capture the pressure drop pattern well enough. The longest lead time model run $(180 \mathrm{hr}$ ) based on 0000 UTC of 26 April has simulated the lowest MSLP value which is good enough with the observation compared to all other simulations. The simulated MCP patterns show relatively less 
severity than the observations. These outcomes indicate the significance and the uncertainty about the appropriate lead time of the model run to forecast maximum intensity.
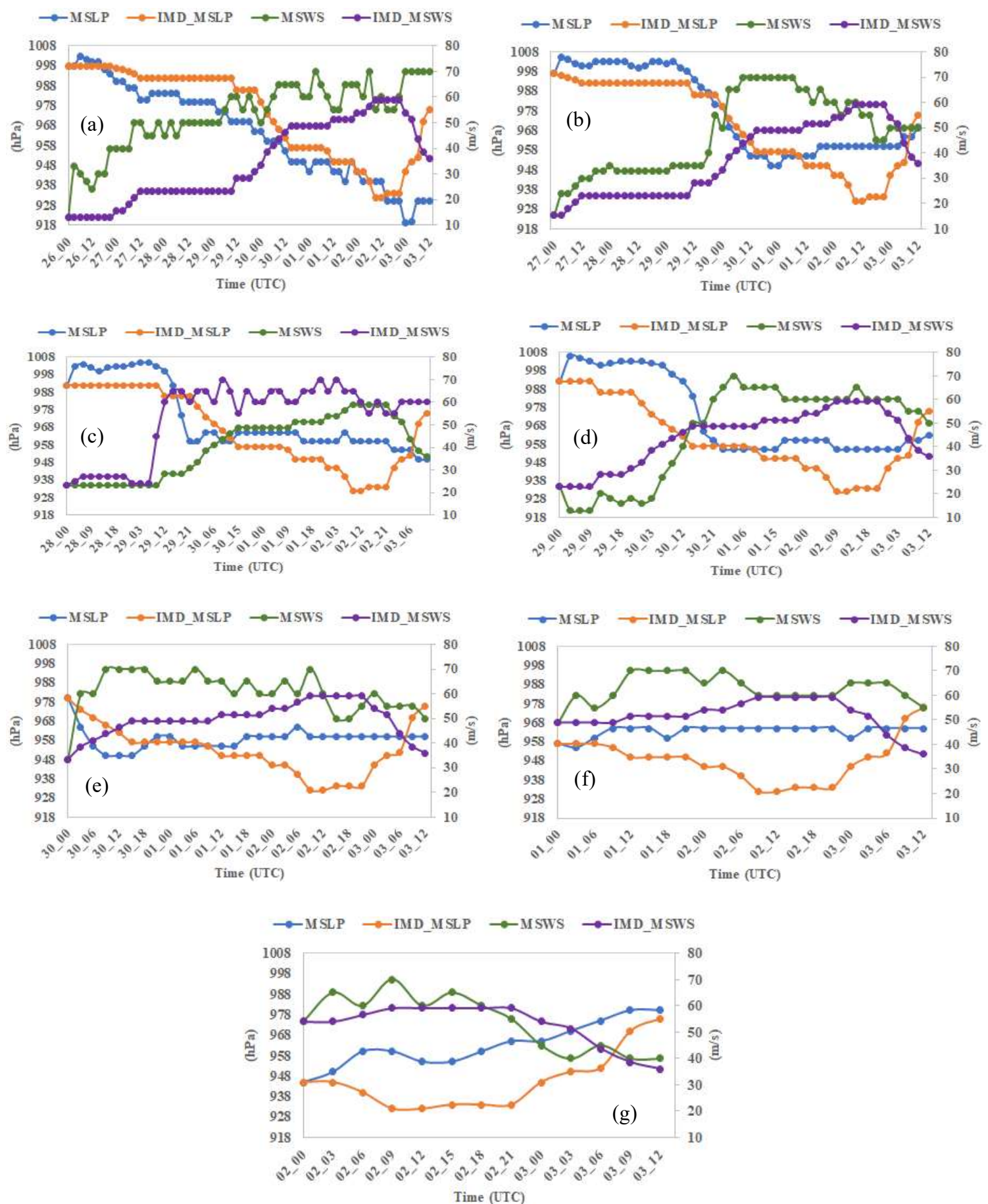

Figure 3: Time series of model simulated MSLP $(\mathrm{hPa})$ and MSWS $\left(\mathrm{m} \mathrm{s}^{-1}\right)$ distribution based on 0000 UTC of (a) 26 April, (b) 27 April, (c) 28 April, (d) 29 April, (e) 30 April, (f) 1 May and (g) 2 May respectively, along with the IMD's observations.

The distribution of model simulated wind speed at $850 \mathrm{hPa}$ level based on 0000 UTC of 26, 27, 28, 29 and 30 April, 1 and 2 May 2019 respectively is displayed in Figure 2(a-g). A small cyclonic circulation is simulated at the initial phase near the equator and neighboring regions throughout the BoB. The circulation pattern becomes stronger over time under convenient conditions. A well-organized convergence zone has been simulated up to 500 $\mathrm{hPa}$ level and the MSWS is determined at the eyewall of the system. 

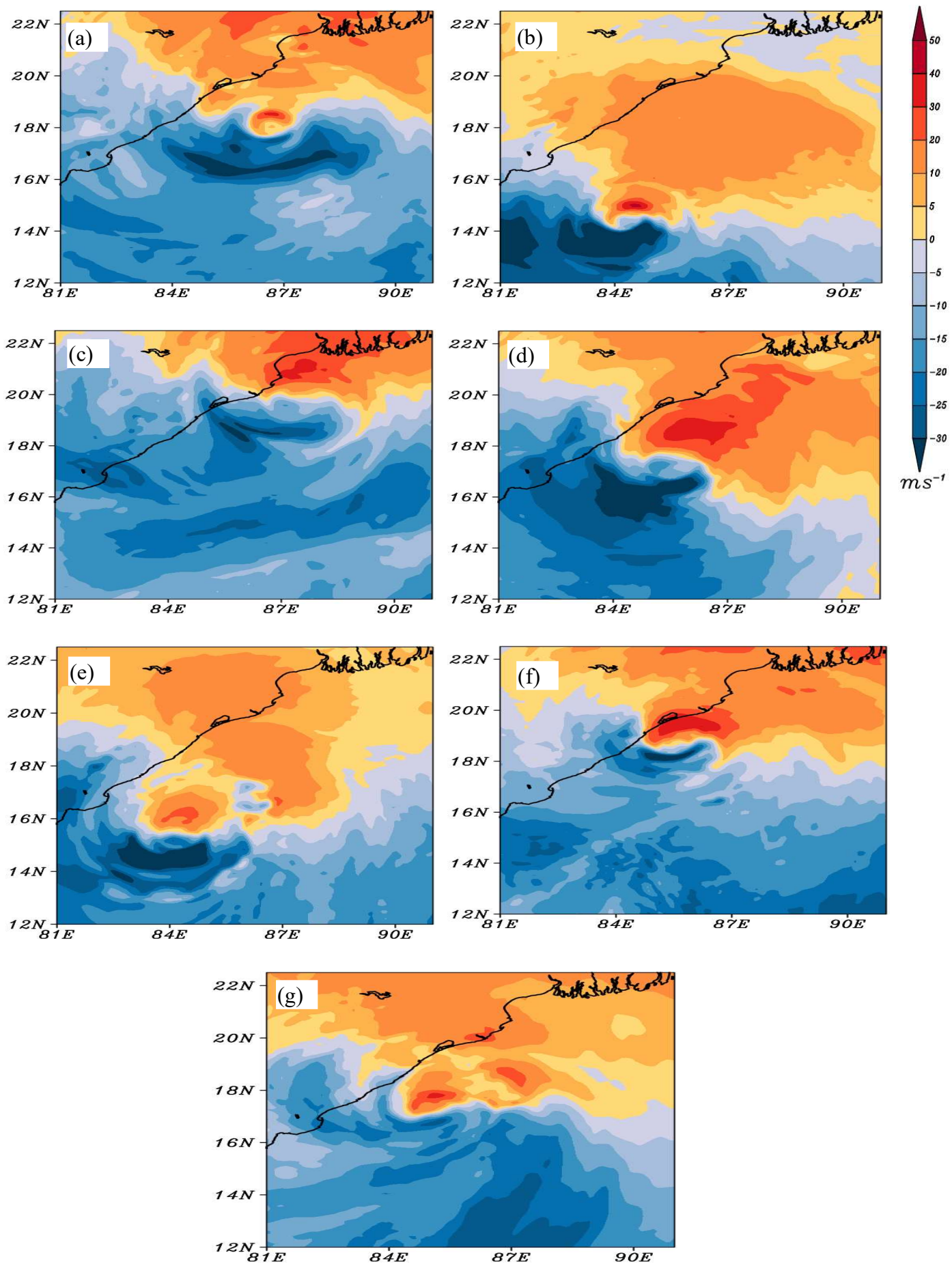

Figure 4: The distribution of model simulated VWS (m/s) of the zonal component of velocity between 200-850 hPa level valid for (a) 0000 UTC of 3 May, (b) 2100 UTC of 30 April, (c) 1200 UTC of 3 May, (d) 1300 UTC of 2 May and (e) 1300 UTC of 1May based on 0000 UTC of 26, 27, 28, 29 and 30, April respectively, (f) 0000 UTC of 3 May and (g) 1000 UTC of 2 May based on 0000 UTC of 1 and 2 May 2019, respectively.

The MSWS is found around 70, 70, 70, 70, 70, 65, and $60 \mathrm{~m} \mathrm{~s}^{-1}$ for the different initial condition-based model run. At the $200 \mathrm{hPa}$ level, a cyclonic circulation is predicted but the pattern of circulation is not well-organized. Though a divergence zone is identified around $200 \mathrm{hPa}$ level, it has a propensity to modify into a convergence zone, which is the indication of the stronger cyclonic rotation. Figure $3(\mathrm{a}-\mathrm{g})$ exhibits the comparison between the 
predicted MSWS outcomes and the observations. Although the pattern of forecasted wind speed follows a similar trend to the observations, the simulated MSWS values overestimate the observed results.
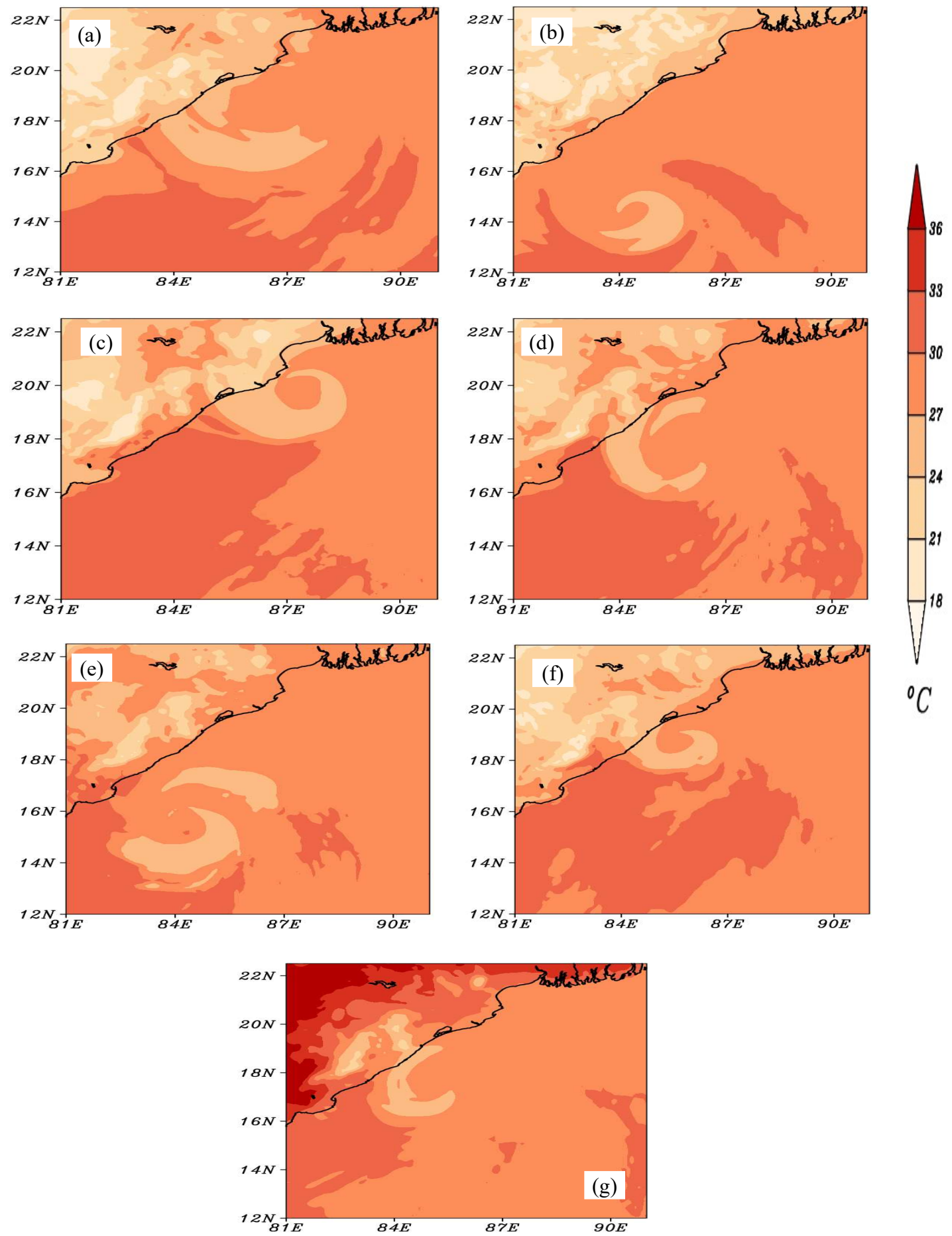

Figure 5: The distribution of model simulated SST $\left({ }^{\circ} \mathrm{C}\right.$ ) valid for (a) 0000 UTC of 3 May, (b) 2100 UTC of 30 April, (c) 1200 UTC of 3 May, (d) 1300 UTC of 2 May and (e) 1300 UTC of 1 May based on 0000 UTC of 26, 27, 28, 29 and 30 April, respectively, (f) 0000 UTC of 3 May and (g) 1000 UTC of 2 May based on 0000 UTC of 1 and 2 May 2019, respectively.

\subsection{Analysis of Sea Surface Temperature and Vertical Wind Shear}

From the simulated VWS distribution analysis, a rising pattern of VWS is simulated at the early stage of the system at both 200-900 hPa and 500-900 hPa levels (Figure 4 (a-g)). This shape of VWS has created an adverse 
condition for system formation. The VWS values begin to decline after 27 April, particularly at the 500-850 hPa level, which ensures favorable conditions for cyclone formation and intensification. The model simulated maximum VWS values at the time of maximum intensity is noted as around 30,40, 35, 30, 20, 40, and 40 $\mathrm{m} \mathrm{s}^{-1}$ and $25,20,25,25,15,25$, and $25 \mathrm{~m} \mathrm{~s}^{-1}$ between $200-850 \mathrm{hPa}$ and 500-850 hPa levels for 180, 156, 132, $108,84,60$, and $36 \mathrm{hr}$ based simulations respectively. The strong VWS values in the upper troposphere influenced the system to substantially decrease its intensity after achieving its peak intensity.

From the model simulated SST distribution at 2-meter height, temperature approximately $\left(\geq 27^{\circ} \mathrm{C}\right)$ is found over the simulated region. $37.02,35.75,35.67,36.00,33.76,34.33$, and $33.77^{\circ} \mathrm{C}$ is the model forecasted average maximum SST for $180,156,132,108,84,60$, and $36 \mathrm{hr}$ model runs, which is sufficiently suitable for the system's formation and intensification. A comparative study has been performed between the predicted maximum and minimum temperatures and the verified maximum and minimum temperatures data of BMD at different stations of Bangladesh. The forecasted maximum and minimum temperatures, respectively, overestimate and underestimate the actual findings.

(a)

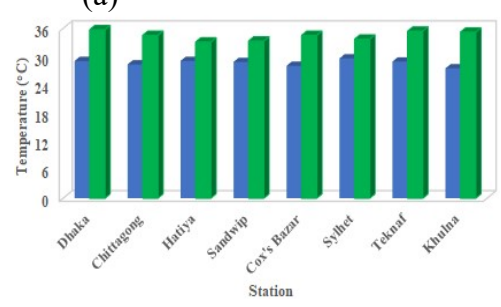

(d)

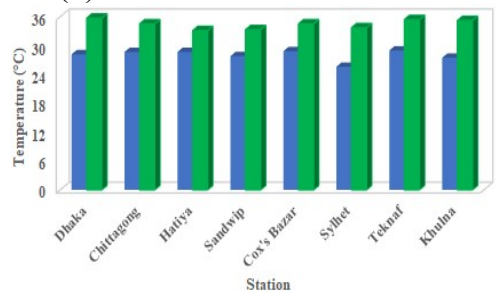

(b)

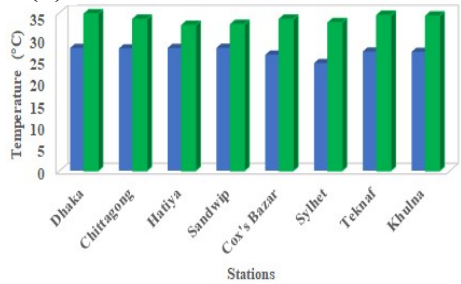

(e)

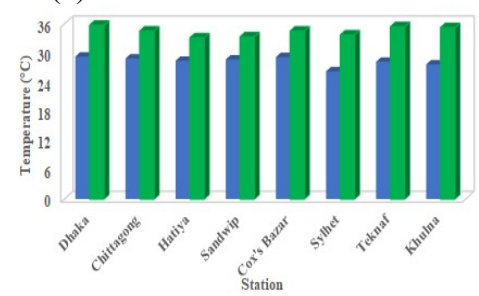

(c)

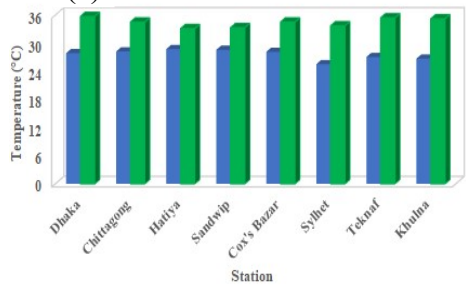

(f)

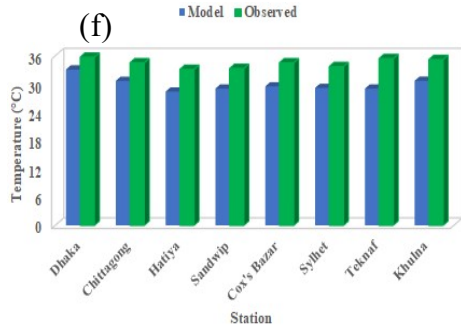

(g) -Model nObserred

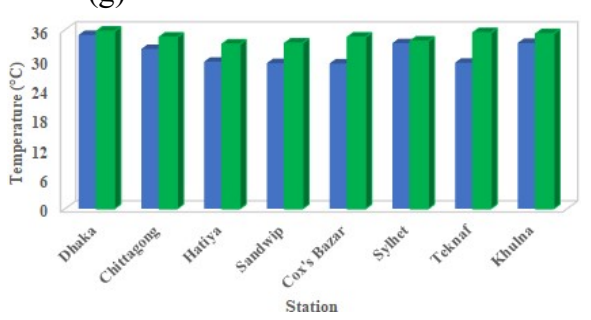

Figure 6: Comparison of model simulated maximum SST $\left({ }^{\circ} \mathrm{C}\right)$ at 2-meter height with the observed results at different stations of BMD on 2 May based on 0000 UTC of (a) 26, (b) 27, (c) 28, (d) 29 and (e) 30 April, respectively and (f) 1 and (g) 2 May 2019, respectively

\subsection{Distribution of Vorticity and Relative Humidity}

The distribution of model simulated relative vorticity at $850 \mathrm{hPa}$ level at the time of model simulated maximum intensity has presented in Figure 7(a-g). Based on the model simulated relative vorticity findings at 850 and 500 $\mathrm{hPa}$ levels, it can be revealed that both negative and positive vorticity are simulated throughout the simulated areas. The maximum positive vorticity is detected at the system's eyewall in both cases. The maximum positive vorticity is determined as around 300,350, 200, 240, 200,300, and $270 \times 10^{-5} \mathrm{~s}^{-1}$, and 240, 180, 240,90, 180, 120 , and $120 \times 10^{-5} \mathrm{~s}^{-1}$ at 850 and $500 \mathrm{hPa}$ levels for $180,156,132,108,84,60$, and $36 \mathrm{hr}$ model runs respectively. This high relative vorticity is very much convenient for convective cloud formation as well as intensification of the cyclone.

According to the model simulated $\mathrm{RH}$ at a $2 \mathrm{~m}$ height, a dynamic southwesterly flow of huge humidity $(\geq 80 \%)$ is found in the northern direction of the simulated region (Figure $8(\mathrm{a}-\mathrm{g})$ ). The maximum RH is identified at the system's eyewall, whereas a relatively less amount of $\mathrm{RH}(\leq 75 \%)$ is noticed at the core of the system. Between 
$(550-200) \mathrm{hPa}$ levels, the RH on top of the system's center is significantly lower $(\leq 70 \%)$ than its surroundings. It is also simulated that the RH has extended vertically to (90-100) \% up to $100 \mathrm{hPa}$ level. This finding indicates that the RH distribution is very much supportive of the system intensification. Comparing with the observed data of BMD, it can be decided that the model can simulate the RH distribution very well.
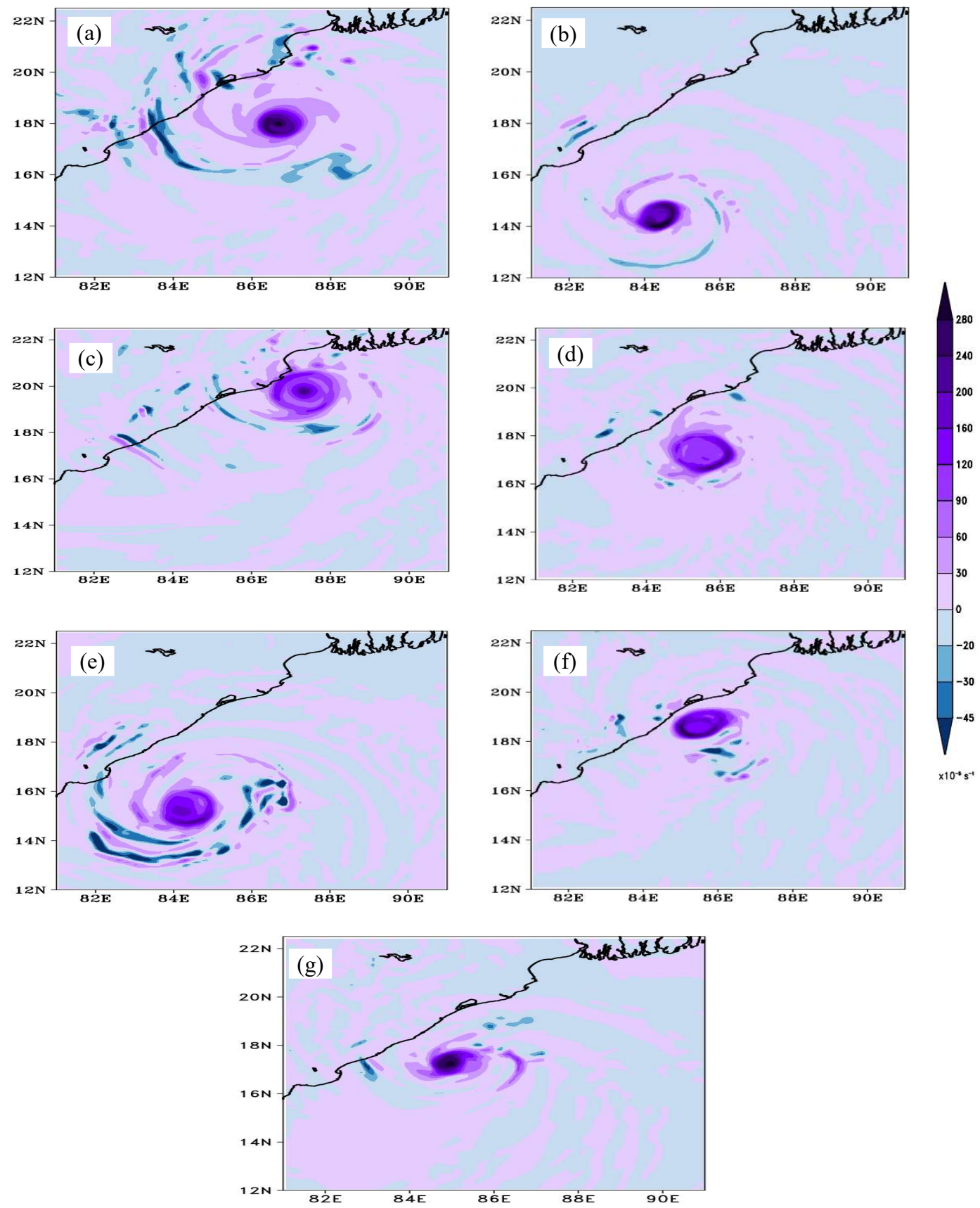

Figure 7: The distribution of model simulated relative vorticity $\left(\times 10^{-5} \mathrm{~s}^{-1}\right)$ valid for (a) 0000 UTC of 3 May, (b) 2100 UTC of 30 April, (c) 1200 UTC of 3 May, (d) 1300 UTC of 2 May and (e) 1300 UTC of 1May based on 0000 UTC of 26, 27, 28, 29 and 30 April, respectively and (f) 0000 UTC of 3 May and (g) 1000 UTC of 2 May based on 0000 UTC of 1 and 2 May 2019, respectively.

\subsection{Distribution of Convective Available Potential Energy and Latent Heat Flux}

From the model simulated Convective Available Potential Energy (CAPE) findings at $850 \mathrm{hPa}$ level, relatively high CAPE values are found at the eyewall of the system center. The simulated maximum CAPE values are determined as around 1000, 1000, 1100, 1800, 2000, 2700, and $1400 \mathrm{Jkg}^{-1}$ for $180,156,132,108,84,60$, and 36 
hr model runs respectively. This high CAPE value indicates that the air parcel would get enough opportunity to rise high enough in the atmosphere to form convective weather systems. These high CAPE values significantly enhance the possibility of severe weather. Finally, it can be deduced that the CAPE value is very much helpful for cyclone formation and intensification.
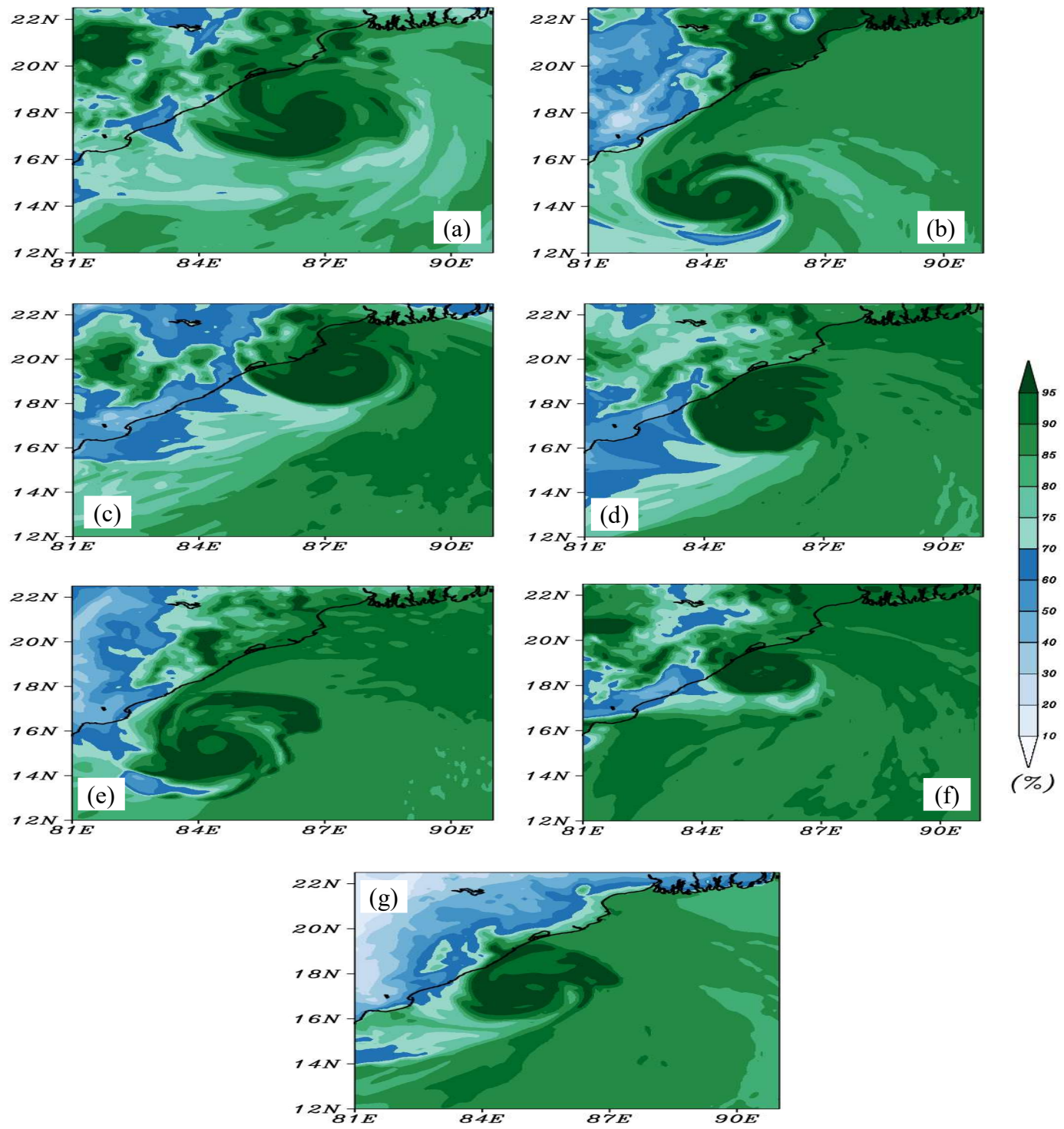

Figure 8: The distribution of model simulated RH (\%) valid for (a) 0000 UTC of 3 May, (b) 2100 UTC of 30 April, (c) 1200 UTC of 3 May, (d) 1300 UTC of 2 May and (e) 1300 UTC of 1 May based on 0000 UTC of 26, 27, 28, 29 and 30 April, respectively and (f) 0000 UTC of 3 May and (g) 1000 UTC of 2 May based on 0000 UTC of 1 and 2 May 2019, respectively.

According to the model simulated Latent Heat Flux (LHF) results at surface level, the maximum LHF is found in several bands around the moat area. It is also noticed that the LHF rises with time for all lead time model runs. The maximum LHF is determined as about $1200,1100,1000,1600,1800,1100$, and $1200 \mathrm{Wm}^{-2}$ based on 0000 UTC of 26, 27, 28, 29 and 30 April and 1 and 2 May 2019 respectively. This high LHF value reveals that the system might absorb enough energy from the sea surface to develop its intensity. 

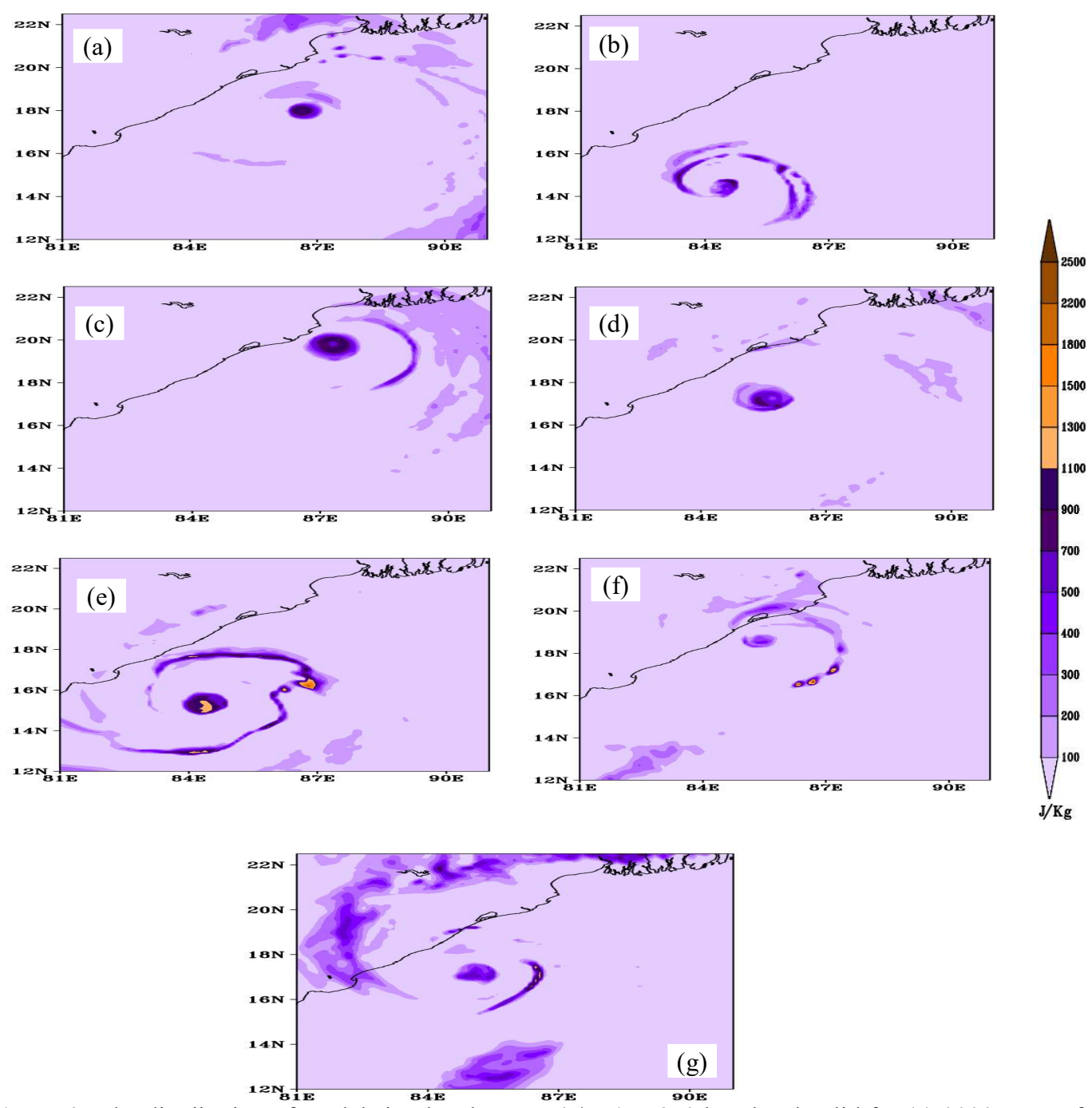

Figure 9: The distribution of model simulated CAPE $(\mathrm{J} / \mathrm{Kg})$ at $850 \mathrm{hPa}$ level valid for (a) $0000 \mathrm{UTC}$ of $3 \mathrm{May}$, (b) 2100 UTC of 30 April, (c) 1200 UTC of 3 May, (d) 1300 UTC of 2 May and (e) 1300 UTC of 1May based on 0000 UTC of 26, 27, 28, 29 and 30 April, respectively and (f) 0000 UTC of 3 May and (g) 1000 UTC of 2 May based on 0000 UTC of 1 and 2 May 2019, respectively.

\subsection{Distribution of Potential Temperature Distribution}

Figure 11 depicts the distribution of model simulated potential temperature up to the upper-tropospheric level at the time of the model's simulated maximum intensity. The simulated potential temperature is calculated at the time of maximum intensity from surface to $100 \mathrm{hPa}$ pressure levels. It is found that potential temperature rises with height, indicating that the rate of change of potential temperature with respect to height is positive. This finding suggests that the unsaturated atmosphere is statically stable. Thus, it can be concluded that potential temperature distribution supports the system in turning into a stable CS (Dolling et al., 2012; Stern et al., 2013).

\subsection{Analysis of Intensity Forecast Errors}

The comparison between the model simulated intensity results and the IMD observed data is presented in Table 1. It is observed that the model can capture the MSWS values well enough. It is also determined that the model can simulate the MCP values reasonably well although it has some errors. Except for the model run based on 0000 UTC of 26 April, the simulated values of the LCP are comparatively higher than the IMD's ECP. Only the largest lead-time model run $(180 \mathrm{hr})$ based on 0000 UTC of 26 April has predicted more severity than the observations. Considering the forecasting error analysis, it can be decided that the model can simulate the intensity features well enough though it has some uncertainty about the appropriate lead time of the model run. It can also be revealed that the model can not measure the rapid intensification of the system very well. 

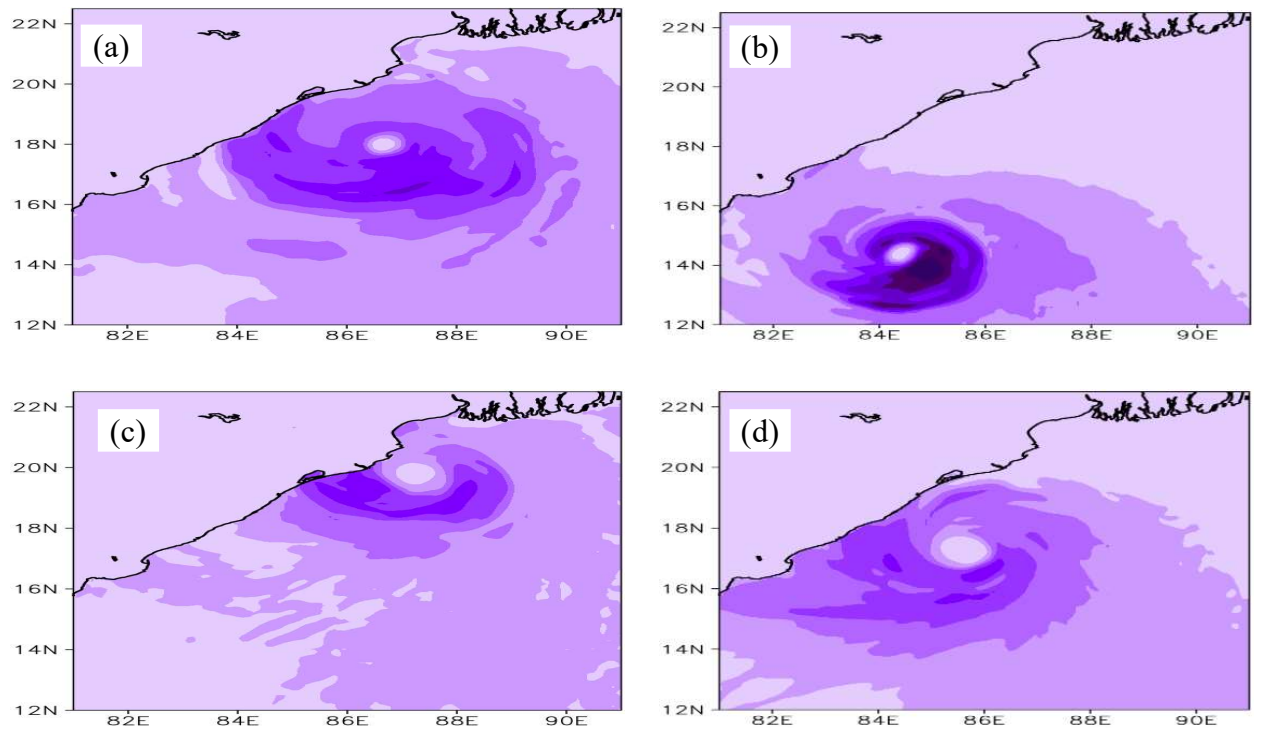

1500
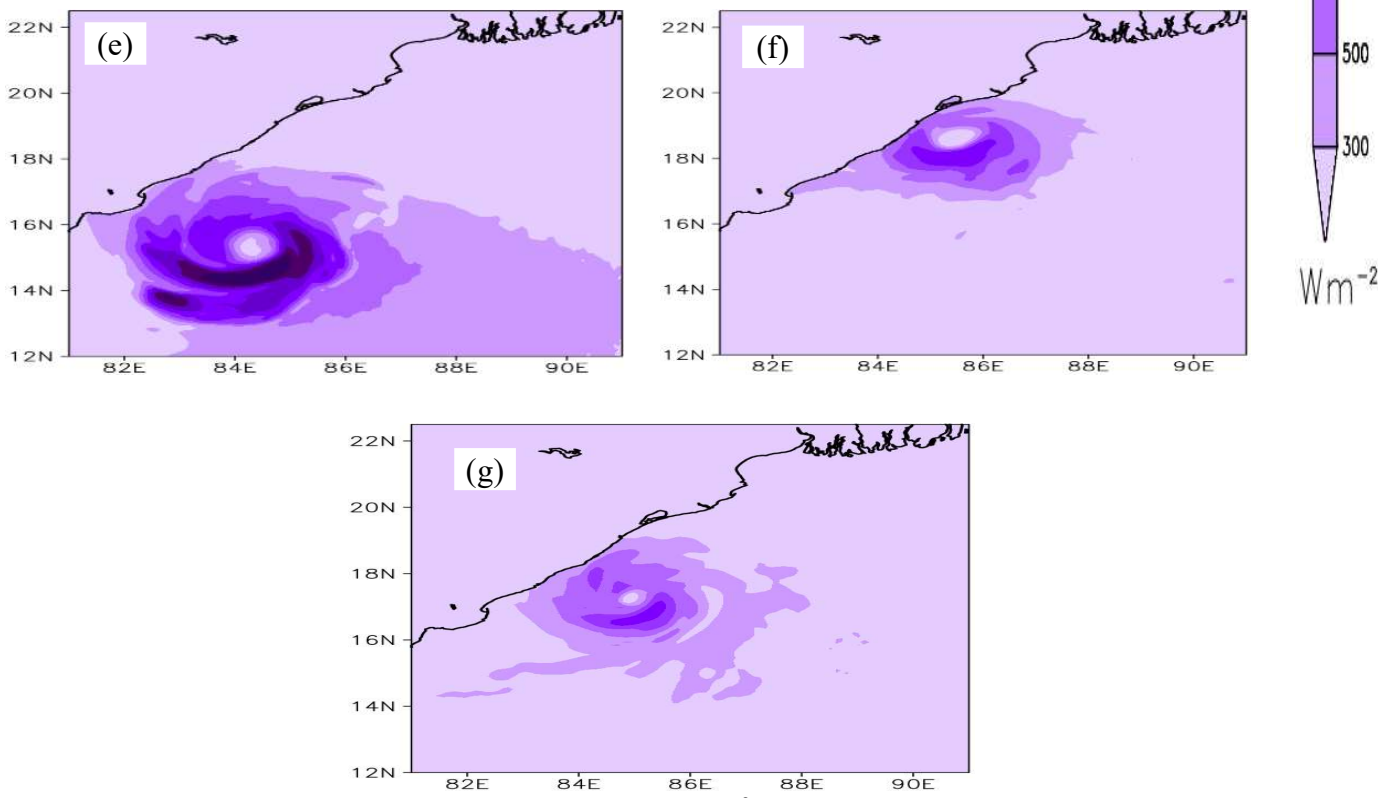

Figure 10: The distribution of model simulated LHF $\left(\mathrm{W} / \mathrm{m}^{2}\right)$ at $850 \mathrm{hPa}$ level valid for (a) $0000 \mathrm{UTC}$ of $3 \mathrm{May}$, (b) 2100 UTC of 30 April, (c) 1200 UTC of 3 May, (d) 1300 UTC of 2 May and (e) 1300 UTC of 1May based on 0000 UTC of 26, 27, 28, 29 and 30 April respectively, (f) 0000 UTC of 3 May and (g) 1000 UTC of 2 May based on 0000 UTC of 1 and 2 May 2019 respectively.

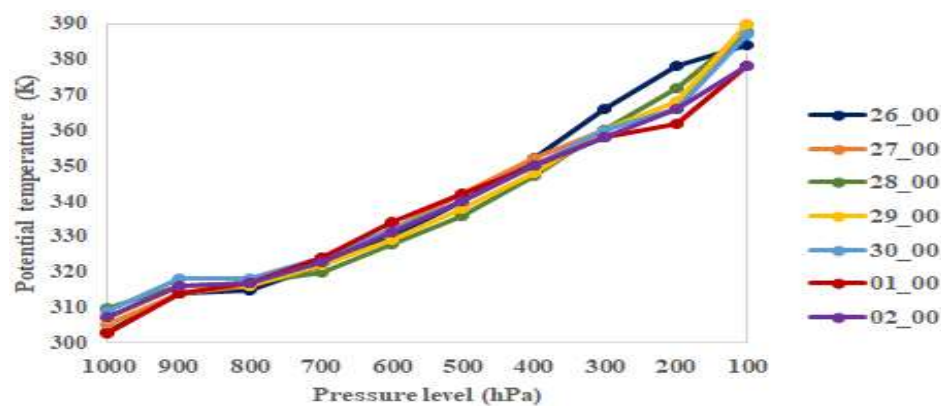

Figure 11: The distribution of model simulated potential temperature $(\mathrm{K})$ at the time of model predicted maximum intensity 
Table 1: Comparison between the model forecasted intensity results and the observed data

\begin{tabular}{cccccccccc}
\hline Base Date/ & \multicolumn{3}{c}{ Intensity Forecast } & \multicolumn{3}{c}{ Observed Intensity } & \multicolumn{3}{c}{ Forecast Error } \\
\cline { 2 - 10 } Time (UTC) & $\begin{array}{l}\text { MCP } \\
(\mathrm{hPa})\end{array}$ & $\begin{array}{c}\text { MSWS } \\
\left(\mathrm{m} \mathrm{s}^{-1}\right)\end{array}$ & $\begin{array}{l}\text { Time } \\
(\mathrm{UTC})\end{array}$ & $\begin{array}{l}\text { ECP } \\
(\mathrm{hPa})\end{array}$ & $\begin{array}{l}\text { MSWS } \\
\left(\mathrm{m} \mathrm{s}^{-1}\right)\end{array}$ & $\begin{array}{l}\text { Time } \\
(\mathrm{UTC})\end{array}$ & $\begin{array}{l}\text { MCP } \\
(\mathrm{hPa})\end{array}$ & $\begin{array}{l}\text { MSWS } \\
\left(\mathrm{m} \mathrm{s}^{-1}\right)\end{array}$ & $\begin{array}{c}\text { Time } \\
(\mathrm{hr})\end{array}$ \\
\hline 26 April /0000 & 919 & 70 & $03 / 00$ & & & & $13 \mathrm{~L}$ & $4 \mathrm{H}$ & $15 \mathrm{D}$ \\
27 April/0000 & 950 & 70 & $30 / 21$ & & & & $18 \mathrm{H}$ & $4 \mathrm{H}$ & $60 \mathrm{E}$ \\
28 April /0000 & 950 & 70 & $03 / 12$ & & & & $18 \mathrm{H}$ & $4 \mathrm{H}$ & $27 \mathrm{D}$ \\
29 April /0000 & 955 & 70 & $02 / 13$ & 932 & 66 & $02 / 09$ & $23 \mathrm{H}$ & $4 \mathrm{H}$ & $4 \mathrm{D}$ \\
30 April /0000 & 953 & 70 & $01 / 13$ & & & & $21 \mathrm{H}$ & $4 \mathrm{H}$ & $20 \mathrm{E}$ \\
01 May /0000 & 960 & 65 & $03 / 00$ & & & & $28 \mathrm{H}$ & $1 \mathrm{~L}$ & $15 \mathrm{D}$ \\
02 May /0000 & 955 & 60 & $02 / 10$ & & & & $23 \mathrm{H}$ & $6 \mathrm{~L}$ & $1 \mathrm{D}$ \\
\hline
\end{tabular}

*L, H, D, E, and 02/13 means less, high, delay, earlier, and 1300 UTC of $02^{\text {nd }}$ May.

\subsection{Statistical Analysis of the Simulated Meteorological Parameters}

The calculated Root Mean Square Error (RMSE) of the simulated results for each lead time model run has been displayed in Table 2. The RMSEs of the simulated MSLP and MSWS values have been computed using the following formula:

$$
\operatorname{RMSE}=\sqrt{\frac{\sum_{\mathrm{i}=1}^{\mathrm{N}}\left(\mathrm{x}_{\mathrm{i}}-\mathrm{y}_{\mathrm{i}}\right)^{2}}{\mathrm{~N}}}
$$

Where, $i$ is a variable, $N$ represents number of data points, $x_{i}$ represents actual observational time series, and $y_{i}$ represents simulated time series. The calculated RMSE values for simulated MSLP and MSWS distributions are $13.5,11.8,14.79,16.74,14.91,19.69$, and $20.12 \mathrm{hPa}$ and $21.1,13.55,16.4,11.1,14.5,13.3$, and $6.42 \mathrm{~m} \mathrm{~s}^{-1}$ for $180,156,132,108,84,60$, and $36 \mathrm{hr}$ based simulations, respectively. Relatively higher RMSE values of simulated MSLP for 60 and $36 \mathrm{hr}$ based simulations indicate that the model can not generate the quick intensification event of the cyclone very well.

Analyzing the RMSEs for MSWS values, it is noticed that reduced lead time model run produces smaller RMSE outcomes. This smaller RMSE values indicate the diminishment of the range of uncertainty in the simulation. Thus, it can be concluded that reduced lead time model run, particularly 24 to $48 \mathrm{hr}$, can be used to forecast the formation and intensification events of TC with minimum uncertainty.

From the analysis of Correlation Coefficient (CC) (Table 3) between the model simulated and the observed findings, it is found that the simulated MSLP is positively correlated with the observed ECP $(\mathrm{CC}=0.52)$. It is also noticed that the wind speed at $850 \mathrm{hPa}$ level has a relatively stronger correlation $(\mathrm{CC}=0.65)$ with the actual wind speed than the wind speed at other pressure level. According to the CC study, all of the simulated parameters have a significant influence on the cyclone's formation and intensification stage. Among them, MSLP, wind flow, SST, LHF, vorticity, RH, and CAPE are the most important factors in genesis as well as development of the system.

Table 2: Statistical analysis of the model simulated outcomes

\begin{tabular}{lccccccc}
\hline & \multicolumn{7}{c}{ RMSE at 0000 UTC of } \\
\cline { 2 - 7 } & 26 April & 27 April & 28 April & 29 April & 30 April & 1 May & 2 May \\
\hline MSLP, hPa & 13.5 & 11.8 & 14.79 & 16.74 & 14.91 & 19.69 & 20.12 \\
MSWS, $\mathrm{m} \mathrm{s}^{-1}$ & 21.1 & 13.55 & 16.4 & 11.1 & 14.5 & 13.3 & 6.42 \\
\hline
\end{tabular}

Table 3: Correlation coefficient between the model simulated results and the observed results

\begin{tabular}{ccccccccccc}
\hline IMD Data & MSLP & MSWS & W8 & W5 & W2 & SST & V8 & V5 & CAPE & LHF \\
\hline ECP & 0.52 & -0.47 & -0.61 & -0.58 & -0.37 & 0.17 & -.41 & -.24 & -.29 & -.51 \\
MSWS & -0.57 & 0.61 & 0.65 & 0.59 & 0.41 & -0.17 & 0.38 & 0.32 & 0.4 & 0.43 \\
\hline
\end{tabular}

*W8, W5, and W2 represents wind speed at 850, 500, and $200 \mathrm{hPa}$ levels respectively.

\subsection{Discussion of Polynomial Approximation}

The observed ECP and MSWS distributions of the selected system has been shown in Figure 12. For both cases of the ECP and MSWS distributions, a polynomial of order six has been identified, which exhibits decent consistency with the pressure drop and wind speed change patterns.

The identified polynomials are:

For ECP: $p=5 \times 10^{-8} t^{6}-7 \times 10^{-6} t^{5}+0.0004 t^{4}-0.0143 t^{3}+0.2156 t^{2}-2.1463 t+1002.4$

For MSWS: $w=10^{-8} t^{6}-3 \times 10^{-6} t^{5}+0.0002 t^{4}-0.0064 t^{3}+0.0654 t^{2}+0.4592 t+10.666$ 


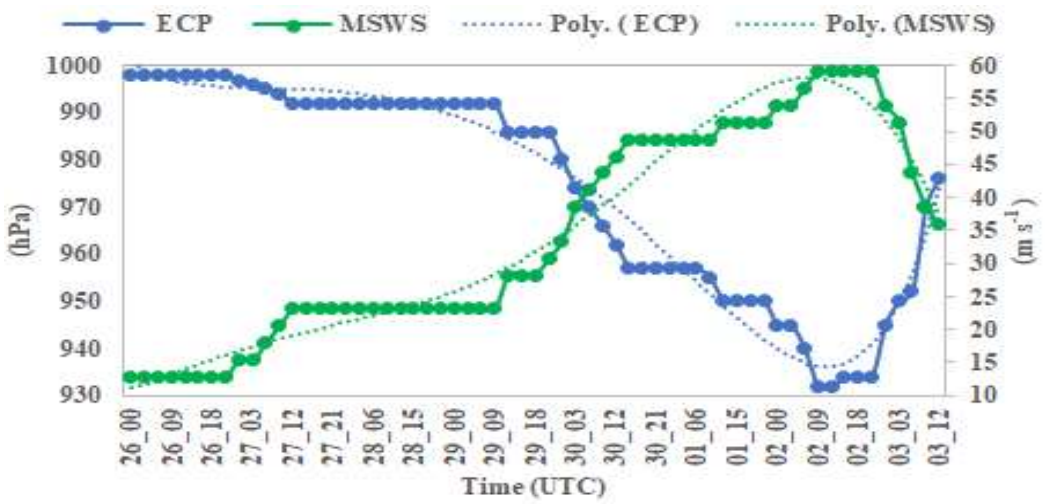

Figure 12: The distribution of observed ECP (blue) and MSWS (green) with their polynomial approximation

Where, $t$ represents the time. The terms with positive and negative coefficients in equation (1) support pressure raises and declines, respectively. Even terms with relatively larger coefficients (containing odd indices) promote pressure drops with time. As time goes on, odd terms with comparatively larger indices dominate negative coefficient terms, and the pressure rises. Four terms in equation (2) support the rising trend of MSWS distribution. As time progresses, the remaining terms can influence the wind speed diminishment due to their combination of large coefficients and indices of the independent variable.

\section{CONCLUSION}

The efficacy of the WRF-ARW model has been studied by simulating the formation and intensification events of the selected VSCS Fani with a single domain of $10 \mathrm{~km}$ horizontal resolution. The following conclusions can be drawn on the basis of the present study:

The model can simulate the MSLP and MSWS change pattern well enough though it has some deviations. The model has simulated the MSLP of $919 \mathrm{hPa}$ and the MSWS of $70 \mathrm{~m} \mathrm{~s}^{-1}$ based on 0000 UTC of $26^{\text {th }}$ April. Comparing with the IMD's observed data, it is found that the model can simulate the MSWS pattern reasonably well. Except for the model run based on $0000 \mathrm{UTC}$ of $26^{\text {th }}$ April, the simulated values of the lowest central pressure are relatively higher than the IMD's observations. The simulated maximum intensity time errors are approximately $15 \mathrm{D}, 60 \mathrm{E}, 27 \mathrm{D}, 4 \mathrm{D}, 20 \mathrm{E}, 15 \mathrm{D}$, and $1 \mathrm{D} \mathrm{hr}$ respectively, where $\mathrm{E}$ and $\mathrm{D}$ represent earlier and delay than the observations.

The rate of change of potential temperature with respect to height is found positive which would assist the system in turning into a stable CS. The distributions of model simulated SST and RH are convenient for cyclone formation and intensification. The model simulated maximum temperature underestimates the observations. On the contrary, minimum temperature overestimates the observations. The simulated $\mathrm{RH}$ distribution shows reasonably good agreement with the observations. The model simulated CAPE and LHF values are also supportive for strong cyclonic circulation. Relatively low VWS values have been simulated at the genesis stage around $29^{\text {th }}$ April, which is favorable for the system's intensification. The model simulated maximum VWS values at the time of maximum intensity is determined as about $30,40,35,30,20,40$, and $40 \mathrm{~m} \mathrm{~s}^{-1}$ and $25,20,25,25,15,25$, and $25 \mathrm{~m} \mathrm{~s}^{-1}$ between (200-850) hPa and (500-850) hPa levels for 180, 156, 132, 108, 84, 60, and $36 \mathrm{hr}$ based simulations respectively. The system's subsequent degradation might be significantly influenced by these dominating VWS values.

According to the $\mathrm{CC}$ analysis, all the simulated parameters have a substantial influence on the cyclone's formation and intensification. Among them, MSLP and wind speed at $850 \mathrm{hPa}$ level have a significantly greater influence than any other parameters. Above all, MSLP, wind flow, SST, LHF, vorticity, RH, and CAPE are the most significant factors in formation as well asintensification of the system. The model has simulated the intensity features well enough, despite some uncertainty regarding the proper lead time of the model run. Reduced lead time model run, particularly 24 to $48 \mathrm{hr}$, can be used to forecast the genesis and intensification events of TC with minimum uncertainty. Finally, it can be concluded that the efficacy of the WRF-ARW model in the genesis and intensity forecast is reasonably well, and it can be applied confidently to forecast TC formation and development events over the BoB. 


\section{REFERENCES}

Alam, M. M., 2020. Sensitivity study of planetary boundary layer parameterization schemes for the simulation of tropical cyclone 'Fani' over the Bay of Bengal using high resolution WRF-ARW model. Journal of Engineering Science, 11(2), 1-18. https://doi.org/10.3329/jes.v11i2.50893

Bender, M. A., Knutson, T. R., Tuleya, R. E., Sirutis, J. J., Vecchi, G. A., Gardner, S. T., and Held, I. M., 2010. Modeled impact of anthropogenic warming on the frequency of intense Atlantic hurricanes. Science, 327(5964), 454-458. https://doi.org/10.1126/science.1180568

Dolling, K. P., and Barnes, G. M., 2012. The Creation of a High Equivalent Potential Temperature Reservoir in Tropical Storm Humberto (2001) and Its Possible Role in Storm Deepening. Mon. Wea. Rev.,140(2),492505. https://doi.org/10.1175/MWR-D-11-00068.1

Dudhia, J., 1989. Numerical study of convection observed during the Winter Monsoon Experiment using a mesoscale two-dimensional model. J. Atmos. Sci., 46, 3077-3107. https://doi.org/10.1175/15200469(1989)046\%3C3077:NSOCOD\%3E2.0.CO;2

Emanuel, K. A., 1991. The theory of hurricanes. Annu. Rev. Fluid Mech., 23, 179-196. https://doi.org/10.1146/annurev.fl.23.010191.001143

Emanuel, K. A., 2005. Increasing destructiveness of tropical cyclones over the past 30 years. Nature, 436, 686688. https://doi.org/10.1038/nature03906

Frank, W. M., and Ritchie, E. A., 2001. Effects of vertical wind shear on the intensity and structure of numerically simulated hurricanes. Mon. Wea. Rev., 129(9), 2249-2269. https://doi.org/10.1175/15200493(2001)129\%3C2249:EOVWSO\%3E2.0.CO;2

Gray, W. M., 1968. Global view of the origin of tropical disturbances and storms. Mon. Wea. Rev., 96(10), 669700. https://doi.org/10.1175/1520-0493(1968)096\%3C0669:GVOTOO\%3E2.0.CO;2

Holland, G. J., 1997. The maximum potential intensity of tropical cyclones. J. Atmos. Sci., 54(21), 2519-2541. https://doi.org/10.1175/1520-0469(1997)054\%3C2519:TMPIOT\%3E2.0.CO;2

Hong, S. Y., Noh, Y., and Dudhia, J., 2006. A new vertical diffusion package with an explicit treatment of entrainment processes. Mon. Wea. Rev., 134(9), 2318-2341. https://doi.org/10.1175/MWR3199.1

Hossain, M. S., Samad, M. A., Sultana, M. R., Malliak, M. A. K., and Uddin, M. J., 2021. Track and Landfall Characteristics of Very Severe Cyclonic Storm Fani over the Bay of Bengal using WRF Model. Dhaka Univ. J. Sci., 69(2), 101-108. https://doi.org/10.3329/dujs.v69i2.56490

Hoyos, C. D., Agudelo, P. A., Webster, P. J., and Curry, J. A., 2006. Deconvolution of the factors contributing to the increase in global hurricane intensity. Science, 312(5770), 94-97. https://doi.org/10.1126/science. 1123560

IMD. 2019. Extremely Severe Cyclonic Storm "FANI" over eastcentral equatorial Indian Ocean and adjoining southeast Bay of Bengal (26 April - 04 May, 2019): Summary; Regional specialised meteorological centre tropical cyclones. Cyclone Warning Division, India Meteorological Department, New Delhi.

Jimenez, P. A., Dudhia, J., Rouco, F. G., Navarro, J., Montavez, J. P., and Bustamante, E. B., 2012. A revised scheme for the WRF surface layer formulation. Mon. Wea. Rev., 140, 898-918. https://doi.org/10.1175/MWR-D-11-00056.1

Kain, J. S., 2004. The Kain-Fritsch Convective Parameterization, An Update. J. Appl. Meteor., 43, $170-181$. https://doi.org/10.1175/1520-0450(2004)043<0170:TKCPAU>2.0.CO;2.

Kessler, E., 1969. On the distribution and continuity of water substance in atmospheric circulations. Meteor. Monogr., 32, 1-48. https://doi.org/10.1007/978-1-935704-36-2_1

Knutson, T. R. and Tuleya, R. E., 2004. Impact of CO2-induced warming on simulated hurricane intensity and precipitation: Sensitivity to the choice of climate model and convective parameterization. J. Clim., 17(18), 3477-3495. https://doi.org/10.1175/1520-0442(2004)017\%3C3477:IOCWOS\%3E2.0.CO;2

Kotal, S. D., Roy, S. K. B., Kundu, P. K., and Ananda, K. D., 2008. A Statistical Cyclone Intensity Prediction (SCIP) model for the Bay of Bengal. J. Earth Syst. Sci., 117(2), 157-168. https://doi.org/10.1007/s12040008-0006-1

Lee, C. S., Edson, R., and Gray, W. M., 1989. Some Large-scale characteristics associated with tropical cyclone development in the North Indian Ocean during FGGE. Mon. Wea. Rev., 117(2), 407-426. https://doi.org/10.1175/1520-0493(1989)117\%3C0407:SLSCAW\%3E2.0.CO;2

Mlawer, E. J., Taubman, S. J., Brown, P. D., Iacono, M. J., and Clough, S. A., 1997. Radiative transfer for inhomogeneous atmospheres: RRTM, a validated correlated-k model for the long wave. J. Geophys. Res., 102, 16663-16682. https://doi.org/10.1029/97JD00237

Saha, M. K., and Khan, N. A., 2014. Changing Profile of Cyclones in the Context of Climate Change and Adaptation Strategies in Bangladesh. Journal of Bangladesh Institute of Planners, 7, 63-78.

Skamarock, W. C., Klemp, J. B., Dudhia, J., Gill, D. O., Barker, D. M., Duda, M. G., Huang, X. Y., Wang, W., and Powers, J. G., 2008. A Description of the Advanced Research WRF Version 3; Mesoscale and Microscale Meteorology Division. National Center for Atmospheric Research, p.113. http://doi.org/10.5065/D68S4MVH 
Sousounis, P. J., Hutchinson, T. A., and Marshall, S. F.,2004. A comparison of MM5, WRF, RUC, and ETA performance for great plains heavy precipitation events during the spring of 2003. Preprints $20^{\text {th }}$ Conference on Weather Analysis and Forecasting, Seattle, Amer. Meteo. Soc.

Srinivas, C. V., Rao, D. V. B., Yesubabu, V., Baskaran, R., and Venkatraman, B., 2013. Tropical cyclone predictions over the Bay of Bengal using the high-resolution advanced research weather research and forecasting model. Q. J. R. Meteorol. Soc., 139(676), 1810-1825.https://doi.org/10.1002/qj.2064

Stern, D. P., and Zhang, F., 2013. How Does the Eye Warm? Part I: A Potential Temperature Budget Analysis of an Idealized Tropical Cyclone. Atmos. Sci., 70(1), 73-90. https://doi.org/10.1175/JAS-D-11-0329.1

Tewari, M. F., Wang, C. W., Dudhia, J., LeMone, M. A., Mitchell, K., Ek, M., Gayno, G., Wegiel, J., and Cuenca, R. H., 2004. Implementation and verification of the unified NOAH land surface model in the WRF model. $20^{\text {th }}$ conference on weather analysis and forecasting/ $16^{\text {th }}$ conference on numerical weather prediction, 1115.

Trenberth, K., 2005. Uncertainty in hurricanes and global warming. Science, 308(5729), 1753-1754. https://doi.org/10.1126/science.1112551

Webster, P. J., Holland, G. J., Curry, J. A., and Chang, H. R., 2005. Changes in tropical cyclone number, duration, and intensity in a warming environment. Science, 309(5742), 1844-1846. https://doi.org/10.1126/science. 1116448

(C) 2021 the JES. Journal of Engineering Science published by Faculty of Civil Engineering, Khulna University of Engineering \& Technology. This is an open access article under the terms of the Creative Commons Attribution-NonCommercialNoDerivatives License, which permits use and distribution in any medium, provided the original work is properly cited, the use is non-commercial and no Modifications or adaptations are made. 